8. Гапанович В.А. Основные направления транспорта / В.А. Гапанович, И.Н. Розенберг // развития интеллектуального железнодорожного Железнодорожный транспорт №4 - 2011. - С. 5-11.

Рецензент д.е.н., професор УкрДУЗТ Кірдіна О.Г. Експерт редакційної колехї̈ к.е.н., доцент УкрДУЗТ Зубенко В.О.

УДК 658.81.65

\title{
ФОРМУВАННЯ СИСТЕМИ УПРАВЛІННЯ ПЕРСОНАЛОМ НА ПРОМИСЛОВИХ ПІДПРИЕМСТВАХ: ТЕОРЕТИЧНИЙ АСПЕКТ
}

\author{
Чобіток В. І., к.е.н., доцент, \\ Волощенко А. В., махістр (УІПА)
}

У статті розглянуто теоретичні аспекти формування системи управління персоналом на промислових підприємствах, проаналізовано та визначено поняття «персонал промислового підприємства», «управління персоналом промислового підприємства». Сформовано напрями діяльності системи управління персоналом на промисловому підприємстві,які складаються з комплексу взаємопов'язаних підсистем. Розроблено систему управління персоналом промислового підприємства.

Ключові слова: персонал промислового підприємства, управління персоналом промислового підприємства, система управління персоналом промислового підприємства.

\section{ФОРМИРОВАНИЕ СИСТЕМЫ УПРАВЛЕНИЯ ПЕРСОНАЛОМ НА ПРОМЫШЛЕННЫХ ПРЕДПРИЯТИЯХ: ТЕОРЕТИЧЕСКИЙ АСПЕКТ}

\author{
Чобиток В. И. к.э.н, доцент, \\ Волощенко А. В., махістр (УІПА)
}

В статье рассмотрены теоретические аспекты формирования системы управления персоналом на промышленных предприятиях, проанализировано и определено понятия «персонал промышленного предприятия», «управление персоналом промышленного предприятия». Сформировано направления деятельности системы управления персоналом на промышленном предприятии, которые состоят из комплекса взаимосвязанных подсистем. Разработана система управления персоналом промышленного предприятия.

Ключевые слова: персонал промышленного предприятия, управления персоналом промышленного предприятия, система управления персоналом промышленного предприятия.

\section{FORMATION OF PERSONNEL MANAGEMENT IN INDUSTRIAL ENTERPRISES: THEORETICAL ASPECTS}

Chobitok V. I., candidate of economic sciences, associate professor, Voloshchenko A. V., MA (Ukrainian Engineering -pedagogical Academy)

The article deals with theoretical aspects of forming the system of personnel management in industrial plants analyzed and defined the concept of "the staff of industrial enterprise", "personnel management of the industrial enterprise." Formed activities of personnel management system in an industrial plant, which consist of a set of interrelated subsystems that include a subsystem of general and line management subsytemplanning and marketing, management subsystem, and taking into account a set of personnel, labor relations management subsystem; subsystem to ensure normal working conditions, the development of personnel management subsystem; management subsystem motivation; subsystem management of social development; subsystem of management organizational structure; subsystem of legal support; information provision subsystem. Select the object (functional management staff and line management) and actors (workers, employees of the working groups) personnel management system of an industrial enterprise A system of personnel management of an industrial enterprise, which includes methods of personnel management system and work with the staff, depend

(C) Чобіток B.I., Волощенко А.В.
Вісник економіки транспорту і промисловості № 50, 2015 
on external and internal factors, and provides an opportunity to assess the effectiveness of human resource management at the industrial enterprise.

Keywords: Staff of industrial enterprises, human resource management of industrial companies, the system of personnel management of the industrial enterprise.

Постановка проблеми та їі зв'язки 3 науковими чи практичними завданнями. Формування системи управління персоналом на промислових підприємствах в сучасних умовах господарювання є актуальним питанням, тому що робота будь-якого промислового підприємства залежить від ефективної системи управління кадрами та їх організації, що відповідає вимогам та тенденціям сьогодення.

Саме, формування ефективної системи управляння персоналом на промислових підприємствах надасть можливість розробляти та впроваджувати інноваційні технології, нові види продукції, що призведе до підвищення рівня фінансових результатів діяльності промислового підприємства та їх конкурентоспроможності як на вітчизняних так і на зарубіжних ринках.

Аналіз останніх наукових досліджень i публікацій. Вітчизняні та зарубіжні вчені приділяли уваги питанню формування системи управляння персоналом на промислових підприємствах, розглянуто та висунуто багато думок, а саме цим питанням займались такі вчені, як: В. Галенко [1], А. Кибанова [2], Дж. М. Іванцевич [3],А. Лобанов [3], Р. Марр [4], А. Фліастер [4], Є. Маслов [5] та інші.

Виділення невирішених частин загальної проблеми. Формування та удосконалення системи управління персоналом на промисловому підприємстві - це багатоаспектний процес, від ефективності якого залежить успішна діяльність цього підприємства та будь-якого суб'єкта господарювання.

Ефективна робота промислового підприємства здійснюється завдяки наявності висококваліфікованих кадрів, правильного розподілу їх функціональних обов'язків та системи управління. Тому необхідно розглядати це питання, ідучи в ногу з сучасними технологіями, відкриттями та інноваціями.

Метою даної статті $\epsilon$ теоретичне обгрунтування формування системи управління персоналом на промислових підприємствах.

Виклад основного матеріалу дослідження. Найбільш важливим елементом продуктивних сил і головним джерелом розвитку економіки $є$ люди (персонал промислового підприємства), їх майстерність та мотивація до господарської діяльності.

Поняття «персонал »походить від лат. Personalis - це наймані працівники підприємства, що мають певний освітній рівень, володіють знаннями, здібностями та досвідом роботи, необхідними для виконання покладених на них обов'язків (функцій), і становлять трудовий потенціал підприємства, що є частиною людського капіталу суспільства. [6].

На сьогоднішній день у вітчизняній науці відсутній однозначний підхід до розуміння економічної категорії «персонал промислового підприємства», аналіз визначення поняття представлено у таблиці 1.

Таблиия 1

Визначення поняття «персонал промислового підприємства»

\begin{tabular}{|c|c|}
\hline Автор & Визначення поняття «персонал промислового підприємства» \\
\hline 1 & 2 \\
\hline Н.П. Николенко[7] & $\begin{array}{l}\text { це, перш за все, люди зі складним комплексом індивідуальних якостей, } \\
\text { серед яких соціально-психологічні відіграють вирішальну роль, це } \\
\text { частина економічного та інноваційного простору підприємства, в якому } \\
\text { радикальні ринкові перетворення мають не лише цілеспрямовано } \\
\text { адсорбуватися (входити у життєве середовище підприємства та } \\
\text { адоптуватися до нього), але й приносити очікувані від них результати. }\end{array}$ \\
\hline $\begin{array}{l}\text { В.Г. Воронкова, } \\
\text { А.Г. Беліченко, } \\
\text { О.М. Попов[8] }\end{array}$ & $\begin{array}{l}\text { це сукупність його працівників, що працюють по найму при наявності } \\
\text { трудових взаємовідносин } 3 \text { роботодавцем, оформлених трудовим } \\
\text { договором (контрактом). }\end{array}$ \\
\hline О.С. Мельничук [9] & $\begin{array}{l}\text { Персонал (від лат. personalis - } \text { особистий })- \text { особовий } \\
\text { підприємства, установи, організації тощо; сукупність кадрів однієї } \\
\text { професійної категорії. }\end{array}$ \\
\hline I.I. Бажан[10] & $\begin{array}{l}\text { визначається як сукупність постійних працівників, які отримали } \\
\text { необхідну підготовку та мають досвід практичної діяльності. }\end{array}$ \\
\hline
\end{tabular}




\begin{tabular}{|l|l|}
\multicolumn{1}{|c|}{ Продовження табл..1 } \\
\hline О.В. Крушельницька [11] & $\begin{array}{l}\text { це основний, постійний штатний склад кваліфікованих працівників, який } \\
\text { формується і змінюється під впливом як внутрішніх (характер продукції, } \\
\text { технології та організації виробництва), так і зовнішніх (демографічні } \\
\text { процеси, юридичні та моральні норми суспільства, характер ринку праці } \\
\text { тощо)чинників. }\end{array}$ \\
\hline Н.А. Сафронов[12] & $\begin{array}{l}\text { це основний склад кваліфікованих працівників підприємства, фірми, } \\
\text { організації. }\end{array}$ \\
\hline С.Ф. Покропивний[13] & $\begin{array}{l}\text { це сукупність постійних працівників, які отримали необхідну професійну } \\
\text { підготовку та (або) мають досвід практичної роботи. }\end{array}$ \\
\hline Т.П. Макаровська[14] & $\begin{array}{l}\text { це сукупність постійних або тимчасових працівників, що отримали } \\
\text { необхідну професійну підготовку або мають досвід практичної роботи. }\end{array}$ \\
\hline О.С. Іванілов [15] & $\begin{array}{l}\text { являє собою сукупність постійних працівників, що отримали необхідну } \\
\text { професійну підготовку та (або) мають досвід практичної діяльності. }\end{array}$ \\
\hline $\begin{array}{l}\text { О.Ю. Сфремов, } \\
\text { І.А. Скопилатов [16] }\end{array}$ & $\begin{array}{l}\text { можна визначити як деяка кількість людей одного трудового колективу, які } \\
\text { мають певні відмінності між собою (посадові, професійні та особистісні) і } \\
\text { організованих по загальному задумом керівництва з урахуванням цих } \\
\text { відмінностей для вирішення завдань, передбачених статутом організації, } \\
\text { фірми, підприємства. }\end{array}$ \\
\hline
\end{tabular}

За результатами аналізу визначення поняття «персонал промислового підприємства» авторами визначено, що - це сукупність працівників, які мають необхідну професійну підготовку або досвід практичної робити та їх склад може змінюватись під впливом зовнішніх та внутрішніх факторів.

Люди (персонал промислового підприємства) - один 3 найважливіших факторів виробництва, тому управління персоналом відіграє найважливішу роль у досягненні промисловим підприємством бажаної мети.

Для реалізації цілей промислового підприємства необхідно мати систему управління персоналом промислового підприємства.
Управління персоналом визнається однією 3 найбільш важливих сфер життя будь-якого промислового підприємства, здатне багаторазово підвищити іiї ефективність.

Управління персоналом промислового підприємства - сукупність механізмів, принципів, форм і методів взаємодії при формуванні, розвитку та діяльності персоналу промислового підприємства, що реалізується як ряд взаємопов'язаних напрямків та видів діяльності [17].

Визначення понятяя «управління персоналом промислового підприємства» за різними авторами представлено у таблиці 2.

Таблиця 2

Визначення поняття «управління персоналом промислового підприсмства» різними авторами

\begin{tabular}{|c|c|}
\hline Автор & Визначення поняття «управління персоналом промислового підприємства» \\
\hline В. Галенко[1] & $\begin{array}{l}\text { це комплекс взаємопов'язаних економічних, організаційних і соціально-психологічних } \\
\text { методів, що забезпечують ефективність трудової діяльності } \\
\text { конкурентоспроможності підприємства. }\end{array}$ \\
\hline $\begin{array}{l}\text { Дж. М. Іванцевич, } \\
\text { А.Лобанов[3] }\end{array}$ & $\begin{array}{l}\text { це забезпечення організації необхідним числом працівників, які виконують необхідні } \\
\text { виробничі функції. Ефективність управління персоналом визначається ступенем } \\
\text { реалізації спільних цілей організації. }\end{array}$ \\
\hline $\begin{array}{l}\text { P. Марр, } \\
\text { А. Фліастер[4] }\end{array}$ & $\begin{array}{l}\text { це діяльність, виконувана на підприємствах, яка сприяє найбільш ефективному } \\
\text { використанню працівників для досягнення організаційних і особистих цілей. } \\
\text { Ефективність управління персоналом визначається ступенем і термінами виконання, } \\
\text { поставлених УП-структурами специфічних, верифікованих завдань. }\end{array}$ \\
\hline Є. Маслов [5] & $\begin{array}{l}\text { це область діяльності, найважливішими елементами якої є визначення потреби, } \\
\text { залучення, введення в роботу, розвиток, контролінг, вивільнення персоналу, а також } \\
\text { структурування робіт, політика винагород та соціальних послуг, управління витратами } \\
\text { на персонал і керівництво співробітниками. }\end{array}$ \\
\hline А. Кибанова [2] & $\begin{array}{l}\text { це системне, планомірно організований вплив за допомогою взаємопов'язаних } \\
\text { організаційних, економічних та соціальних заходів на процес формування та } \\
\text { перерозподілу робочої сили на рівні підприємства, на створення умов для } \\
\text { використання трудових якостей працівників } 3 \text { метою забезпечення ефективного } \\
\text { функціонування підприємства і всебічного розвитку зайнятих у ньому працівників. } \\
\text { Ефективність управління персоналом визначається найбільш повною реалізацією } \\
\text { поставлених цілей при скороченні витрат на персонал. }\end{array}$ \\
\hline
\end{tabular}


Таким чином, визначено, що управління персоналом промислового підприємства - це діяльність яка повинна враховувати потреби, можливості,знання, уміння та стаж роботи, 3 метою ефективного використання потенціалу персоналу та забезпечувати планомірний i організаційний вплив за допомогою організаційних, економічних та соціальних заходів зі створенням належних умов праці,що надасть можливість підвищити показники продуктивності праці та рівня конкурентоспроможності промислового підприємства.

Формування системи управління персоналом на промисловому підприємстві є дуже важливим, тому що керівнику промислового підприємства i керівникам підрозділів потрібно правильно проводити систему оцінки персоналу, правильно ставити цілі.

Система управління персоналом промислового підприємства - це система в якій реалізуються функції кадрового менеджменту
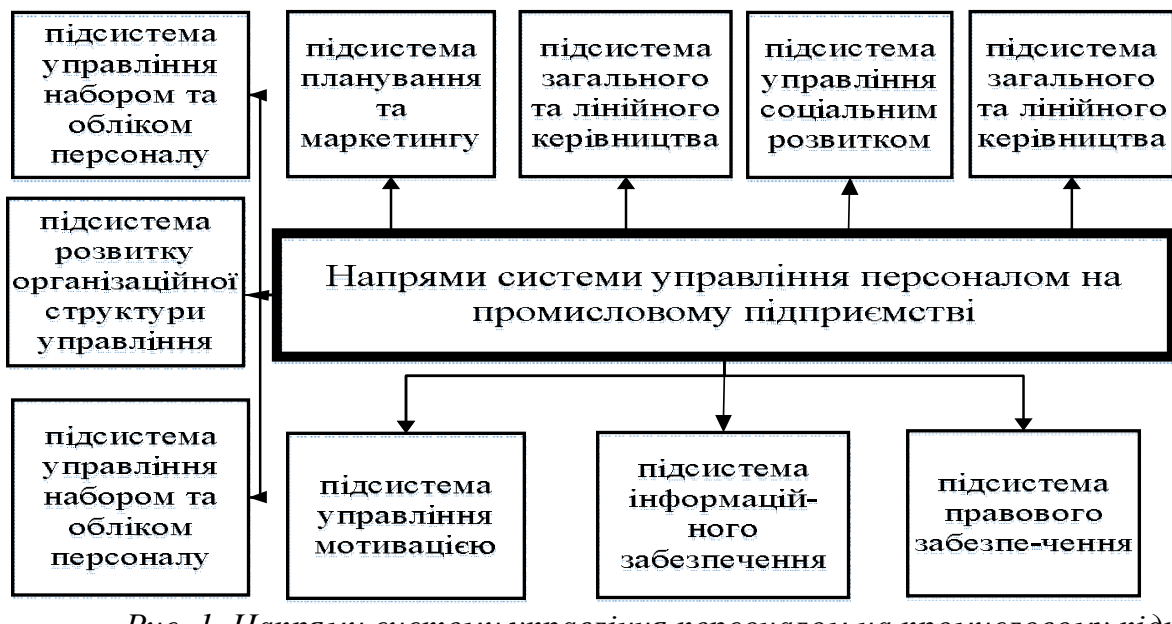

(планування, організація, мотивація, контроль) на застосуванні системи методів управління та використання існуючого ресурсного забезпечення

Система управління персоналом на промисловому підприємстві складається 3 комплексу взаємопов'язаних підсистем (елементів) [18; с.112-116].

Підсистема системи управління персоналом промислового підприємства - це комплексний напрямок кадрової роботи, який виступає складовою частиною цілісної управлінської системи на промисловому підприємстві.

Підсистема - це виділені за функціональними елементами або організаційними ознаками частини системи, кожна із яких виконує певні завдання, працює автономно, але спрямована на вирішення загальної мети [2; с.61].

Система управління персоналом на промисловому підприємстві має багатоступеневу структуру 3 великою кількістю напрямів діяльності, які наведено на рис. 1.

Рис. 1. Напрями системи управління персоналом на промисловому підприсмстві

Систему управління персоналом промислового підприємства складають об'єкти та суб'єкти.

Об'єкт (керований елемент, тобто те, що вивчається) - це основні компоненти системи управління персоналом: підбір, розстановка, оцінка, стимулювання і т.д. [18]

Суб'єкт управління персоналом - це той, від кого залежить якість прийняття управлінських рішень, а, отже, наступний результат діяльності працівника, підрозділу і всього підприємства в цілому. Суб'єкт управління персоналом - це той, хто володіє функціями управління персоналом; займає активну положення по відношенню до об'єкта управління; має для цього необхідні можливості. [18]

Головною метою управління персоналом $\epsilon$ отримання найефективнішої роботи персоналу та внесок у прибуток промислового підприємства, який досягається завдяки їх забезпечення висококваліфікованими та зацікавленими працівниками через задоволення соціальних потреб людини на виробництві.

Відтак, само поняття управління персоналом у деякому ступені є умовним, оскільки передбачає не командування людьми, а створення умов для найефективнішого використання людських ресурсів та кожного працівника окремо.

Система управління персоналом промислового підприємства має свою структуру та змінюється під впливом зовнішніх та внутрішніх чинників (рис. 2).

Структура системи управління персоналом залежить від масштабів промислового підприємства, його територіального розташування, характеру діяльності і інших факторів та одним 3 ключових напрямків підвищення рівня конкурентоспроможності промислового підприємства. 


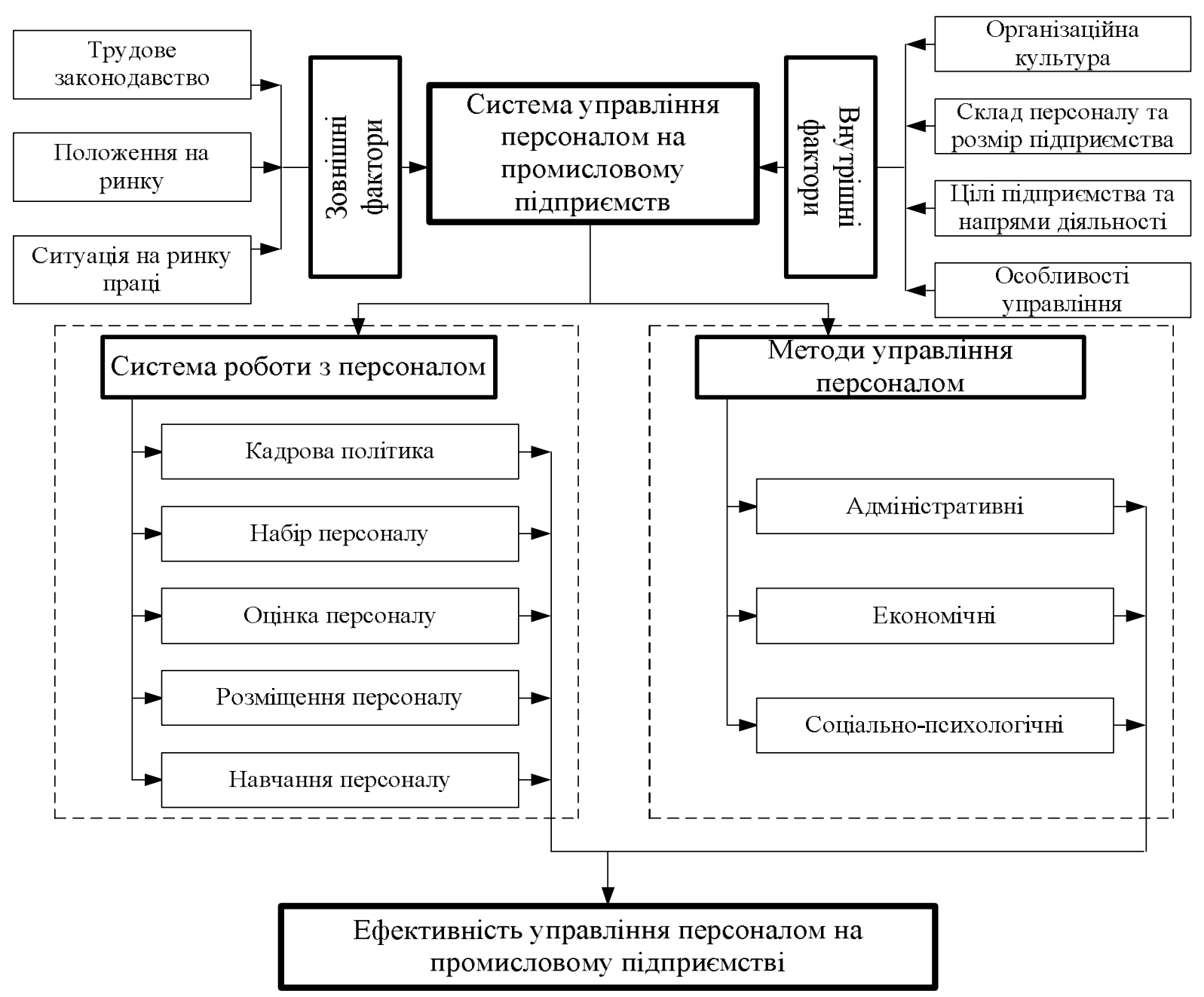

Рис. 2. Система управління персоналом промислового підприємства

У малих i середніх промислових підприємствах одна підсистема може виконувати функції декількох функціональних підсистем, при різних умовах одні підсистеми можуть бути ліквідовані, змінені, перетворені.

Висновки. Ефективна робота промислового підприємства здійснюється завдяки наявності висококваліфікованих кадрів, правильного розподілу їх функціональних обов'язків та системи управління, яка значною мірою залежить від впливу зовнішніх та внутрішніх факторів, а також системи роботи та використання методів управління персоналом.

В статті за результатами аналізу визначення поняття «персонал промислового підприємства» авторами визначено, що - це сукупність працівників, які мають необхідну професійну підготовку або досвід практичної робити та їх склад може змінюватись під впливом зовнішніх та внутрішніх факторів.

Також, визначено, що управління персоналом промислового підприємства - це діяльність яка повинна враховувати потреби, можливості,знання, уміння та стаж роботи, 3 метою ефективного використання потенціалу персоналу та забезпечувати планомірний i організаційний вплив за допомогою організаційних, економічних та соціальних заходів зі створенням належних умов праці,що надасть можливість підвищити показники продуктивності праці та рівня конкурентоспроможності промислового підприємства.

Отже, ефективна система управління персоналом $\epsilon$ одним 3 ключових напрямків підвищення рівня конкурентоспроможності промислового підприємства.

\section{СПИСОК ЛІТЕРАТУРИ}

1. Галенко В.П. Управління персоналом і ефективність підприємств. [Текст] / В.П. Галенко. - СПб: СПбГУЕФ - 1994. - 54 с.
2. Кибанова
A.Я.
Управління персоналом організації [Текст] / flood ред. 
Кибанова А.Я.,Шекшня С.В.- М.: ИНФРА-М, 1998. $-62 \mathrm{c.}$.

3. Марр Р.Людські ресурси управління. [Текст] / Марр Р., Фліастер А. -М.: Справа, 1993. C.11-22

4. Людина i праця:словник[авт.-уклад. Маслов С.В.] [Текст] - 1994. №1..- 127 с.

5. Федорняк Л.С. Сутність поняття “персонал” підприємства [Текст] / Федорняк Л.С. // Економіка: проблеми теорії та практики. Збірник наукових праць. - Дніпропетровськ. - 2007. - Вип. 181: T 7. - С. $12-33$.

6. Николенко Н.П. Менеджмент человеческих ресурсов [Текст]: [практическое пособие] / Н.П. Николенко; Н.П. Николаенко. Москва: Страховое Ревю, 2004. - 356 с.

7. Мельничук Д.П. Трудовий потенціал в системі оцінки людського капіталу України [Текст] / Д.П. Мельничук // Вісник ЖДТУ. Економічні науки. - 2007. - № 4(42). - С. 219-181.

8. Бажан I.I. Сутність категорії «трудовий потенціал» та іiї економічна природа [Текст] / I.I. Бажан // Формування ринкових відносин в Україні. - 2003. - № 1(20). - С. 69-73.

9. Крушельницька О.В. Управління персоналом [Текст]: навчальний посібник для студ. вищ. навч. закладів / О.В. Крушельницька, Д.П. Мельничук ; М-во освіти і науки України. - 2-ге вид., перероб. і доп. - К. : Кондор, 2009. - 308 с.
10. Е.В. Арсенова. Экономика предприятия [Текст]: учебник / Е.В. Арсенова, Я.Д. Балыков, И.В. Корнеева и др.; Под ред. Н.А. Сафронова. - М.: Юристъ, 1998. - 581 с.

11. Покропивний C. Ф. Экономика предприятия: Учебник [Текст] / Подобщ. ред. д-ра екон. наук, проф. С.Ф. Покропивного. - Пер. с укр. 2-го перераб. и доп. изд. - К.: КНЭУ, 2002. - 608 с. 12. Макаровська Т.П. Економіка підприємства [Текст]: навч. посіб. / Т.П. Макаровська, Н.М. Бондар. - К. : МАУП, 2003. $304 \mathrm{c}$.

13. Іванілов О.С. Економіка підприємства [Електронний ресурс] : підручник / О.С. Іванілов. К. : Центр учбової літератури, 2009. - 728 с.

14. Скопылатов И.А. Управление персоналом [Текст]: учебноепособие для студентоввузов / И.А. Скопылатов, О.Ю. Ефремов. - СПб.: Изд-во Смольного ун-та, 2000. - 400 с.

15. Меньшикова М.А. К вопросу об управлении персоналом как к системе и как к интегрированной подсистеме организации [Електронний ресурс] / М.А. Меньшикова // Ученые записки Курского государственного университета. - 2008. - № 3(7). - Режим доступу: http://scientific-notes.ru/pdf/007-07.pdf.

16. Шегда, А.В. Учебное пособие: Основы менеджмента [Текст] / А.В. Шегда - К.: Товариство «Знання», КОО, 1998. - 512 с.

Рецензент д.е.н., професор УІПА Прохорова В.В. Експерт редакційної колегї̈ к.е.н., дочент УкрДУЗТ Токмакова І.В. 